\title{
Travellers in storied landscapes: a case study in exchanges and heritage
}

\author{
Isabel McBryde
}

We are all travellers. Despite Beaudelaire's claim that the true traveller is driven solely by the impulsion to move on ('pour partir'), most travel with intent to arrive. Some of us explore daunting landscapes in search of knowledge, or seeking spiritual awareness in the solitude of such vast spaces. Others may journey in the mind to find further intellectual or spiritual depths. In societies of many traditions travel of both kinds has a long history, as have religious pilgrimages to places of sacred associations and power (Dessaix 2000). The western European medieval Christian pilgrim route to Santiago de Compostela (El Camino de Compostela) comes to mind, as does the Hadj, the holy journey to Mecca in Islamic tradition.

This paper explores the movement of people and goods across a landscape - how and why they travel. It considers what meanings and values are ascribed to places within that landscape or to the lines of travel followed. The context is the Aboriginal landscape of east central Australia, considering as a case study the cultural routes that converge on the famous ochre deposits of Pukardu Hill near Parachilna in the Flinders Ranges of South Australia. As well as discussing the traditional Aboriginal values for these routes and the ochre mines, it will consider how we Australians as a nation regard as heritage and protect these Aboriginal places, still of vital importance to the custodial culture. This resonates with questions of Reconciliation and cross-cultural respect at a time when they are major social and political issues in Australia. Such issues were important to anthropologist Isobel White, who throughout her life cared intensely for social justice and equity. The discussion I dedicate to Isobel (Sally) White, whose research on the life of Aboriginal women in arid Australia included work with the Adnyamatharha of the Flinders Ranges. These people had ceremonial and exchange links with groups in Arandic central Australia and the Cooper/ Lake Eyre Basin as well as with Western Desert speakers of the Nullarbor Plain whose lives Sally White shared over many years. In earlier times similar links existed between people of the Ranges and the Wirangu and Mirning of the Nullarbor. The culture of these groups was recorded by Daisy Bates whose life and work were the subject of major research by Sally White (White 1985a, 1993).

Sally White herself was a traveller. Her life's journey involved constantly re-establishing herself and her family as she and Michael White moved from England to the United States and then to Australia to an appointment in Canberra. A return to the 
States was followed by Michael's taking up a chair in Melbourne. His research took them back and forth across the Nullarbor, giving Sally exceptional opportunities for long-term work with the women of the Yalata community (see White 1985b and Aboriginal History vol. 23).

In the early 1970s Sally White joined Luise Hercus to work on Adnyamathanha social organisation as part of a socio-linguistic study of language components as indicators of the categorisation of certain social relationships. The study developed from Schebeck's challenging interpretation of Adnyamathanha personal pronouns (Schebeck et al. 1973).

Sally White's field journal for the three-week period in January 1970 reflects the intellectual drive and energy of these dedicated researchers, as well as their field work ethos. Each day had its crowded programme of travel and work with the Aboriginal people consulted. Yet always this could be stretched to accommodate the needs and concerns of their Aboriginal colleagues. Long hours of driving and tight schedules are recorded with few hints that this was field work in the arid zone in January. University vacation was the only time that these two academic teachers could spare for the luxury of field research. In the few weeks they achieved much, all with cheerful enthusiasm and consideration for those who shared their linguistic knowledge and traditional stories with Luise Hercus and guided Sally White through the intricacies of their social relationships and terminology. The research was a pioneer cross-disciplinary study.

In the field they travelled the western slopes of the Flinders Ranges north to Marree (Fig. 1). The route took them through Adnyamathanha lands to Arabana country and the southern fringes of the Simpson Desert to that of Wangkangurru speakers Jimmy Russell Wanga-mirri and Mick McLean Irinjili, Luise Hercus' long-term linguistic associates (Figs 2,3). Their line of travel followed the early settler road and rail links, routes determined by the location of water sources. It also followed a more ancient line of travel: the traditional route of Wangkangurru expeditions from the desert southward to acquire red ochre from the great quarry at Pukardu Hill near Parachilna (Fig. 1). Along the eastern flanks of the Ranges lay the line of travel used by the expeditions of Diyari and Yandruwantha men to Pukardu Hill. They were also annual, ritual journeys following strictly prescribed routes.

So we can situate Luise Hercus and Sally White as travellers in search of new knowledge and understanding. Their research was based on the tenets of western knowledge systems, creating its own academic cultural landscape. Yet they also moved within the cultural landscapes of their Aboriginal associates. Further, they followed routes long established by Aboriginal groups who travelled not only to acquire valued ochre but also to fulfil ceremonial obligation and the education of young initiates (Jones 1984). On their journey the groups visited and celebrated in song places of numinous power, for they followed routes established and prescribed by ancestral beings. Among these were the beings responsible for the creation of the ochre deposits at Pukardu Hill.

Sally White and Luise Hercus completed their January 1970 fieldwork where it had begun, at Port Augusta. The Aboriginal women there celebrated this with an inma: among the songs sung by the two groups of women involved was part of the Urumbula cycle (White field journal for January 1970). 


\section{Context for a case study: story lines, exchange, cultural routes and cultural landscapes as cultural heritage}

In 1993 Spain nominated the Pilgrim Route El Camino de Compostela for inscription on UNESCO's World Heritage List. In doing so it made a significant statement about relationships between human culture, human history and the landscape. That the nomination could be made, and successfully, marked significant changes in national and international perceptions of cultural heritage - from emphasis on the monumental, architectural or archaeological 'site' to recognition of the social values of related places within a landscape. Although this nomination itself included a string of monuments and sites, it opened the way for the inclusion of places that might present no archaeological documentation of those social values. Such recognition was especially significant for evaluation of places of non-western, non-urban cultures of the indigenous peoples of the New World, the Pacific and Australia.

The contrast between the urbanised western cultures and those of non-urban societies provides the framework for fascinating essays in a recent World Bank publication. lts editors note (Serageldin et al. 2001: 334):

The World Heritage list contains 100 historic cities and about 200 entries referring to sacred places. The widespread representation of these categories demonstrates that they are at the very core of the concept of cultural heritage, serving as strong roots of people's identities, and are the basis of the definition of any culture.

Lévi-Strauss (2001: 375), author of the chapter on historic cities and sacred places, recognises that 'non-built sacred sites are an extremely important subject to which sufficient attention has not been paid'. In his view they show specific attributes in their size, their simple components, their spiritual function and sacred status. However, he stresses that

beyond these differences are deep ties that bind them, specificities that make them different from other categories of properties and to which special attention must be paid when we have to preserve or restore them.

This comment has wider reference, as he would recognise. It is applicable to such places in the cultural heritage of non-urban cultures. It is clearly demonstrated in Patricia Parker's chapter on Native American cultural heritage places in the same volume.

Significant cultural heritage places of these non-urban cultures often comprise linked sets. Each component might be unspectacular in itself but might contribute to a total system which could be of paramount value. The Aboriginal cultural heritage of southwestern Tasmania provides an example. lts status as World Heritage of 'outstanding universal value' was strongly contested in the 1980s on exactly this issue.

From 1992 the range of cultural places recognised in the UNESCO Operational Guidelines for the World Heritage Convention 1972 included a new entity: cultural landscapes. It 'embraces a diversity of manifestations of the interaction between humankind and its natural environment.' (UNESCO 1999, para 37) with three main categories (UNESCO 1999, para $39 \mathrm{i}$-iii). The first is the humanly designed or created landscape such as a garden or parkland. The second, the organically evolved landscape, results from human imperatives (e.g. social, economic) developing over time distinct forms in response to the natural environment. This includes both 'relict', in the sense of past, no longer in use, but still visible landscapes, and 'continuing landscapes' which fulfil active social roles in contemporary traditionally-oriented societies. The third cate- 
gory is the 'associative cultural landscape' described as holding high values 'by virtue of the powerful religious, artistic or cultural associations of the natural element rather than material cultural evidence'. This may 'be insignificant or even absent'. The first cultural landscapes to be inscribed as such on the World Heritage List in 1994 were Tongariro in New Zealand and Uluru Kata Tjuta in Australia. Both were nominated as associative cultural landscapes for their spiritual associations and traditional roles in local societies, respectively Maori and Anangu.

Recently considerable attention has been directed to the question of 'heritage values' in both national and international arenas. The creation of new categories reflects this concern, as does continuing debate on questions of the diversity of human cultural heritage. Was this adequately represented in the World Heritage Convention's Operational Guidelines categories? Many argue that these reflect primarily the values which have dominated the evolution of heritage conservation in western societies. In their view the 'monumentalist' approach evident in practice, and in the World Heritage Convention's Operational Guidelines until recently, necessarily ensured a neglect of the heritage of Oceania, Africa and much of Asia and the Americas. Secretary-General of International ICOMOS (International Council on Monuments and Sites), Jean Louis Luxen, has since acknowledged this (Luxen 2000: 2). So 'authenticity' and questions of 'representativeness' and the recognition of cultural diversity have been central to ongoing debates in ICOMOS and UNESCO's World Heritage Committee (Domicelj and Marshall 1994; Larsen 1995; Buggey 1996; Titchen 1996; McBryde 1997a) focused on developing a global strategy to accommodate the concerns identified (see von Droste et al. 1995). Seminal in this has been the new emphasis on what are termed intangible values. We might simply call them social values. Jane Lennon (1997) has stressed that within the tangible layers of the material physical record of human use of a landscape (the landscape as cultural artefact):

are human meanings related to the fact that landscapes are a record of history where memory, symbolism and signs of the past, as well as tangible physical remains, are held. Herein lies the basis for contemporary cultural significance found in landscapes because meanings are at the heart of community attachment to places and to the development of cultural heritage places.

For those concerned with Australia's Indigenous cultural heritage such changes, both conceptual and procedural, are particularly welcome. They allow consideration of a range of places significant to Indigenous groups previously ill-accommodated by the categories and criteria of the World Heritage Committee's Operational Guidelines. Until recently many of the registers of national and state heritage agencies in Australia also lacked categories relevant for cultural landscapes or for places whose primary values are social or symbolic.

So far Australian attention has focused on 'associative' or 'continuing' cultural landscapes, embedded in enduring Indigenous traditional practices and beliefs. Aboriginal Australia can provide many outstanding examples of these, well justifying the recognition of heritage listing at national and international levels. However, categories recognised by International ICOMOS, and so acceptable to UNESCO's World Heritage Committee, now include other relevant entities. These are Associative Sites, Commemorative Sites, and Cultural Routes or Itineraries. For the last, though the line of travel may be marked by specific places with identifying material traces, it is the route itself 
which is regarded as the 'cultural property' (Luxen 2000). This is of course, an intangible, memorialised in the mind and seen with the mind's eye. Examples include pilgrim routes such as that to Santiago de Compostela (El Camino de Compostela), and the Hadj routes to Mecca, as well as trade routes like the Silk Road, the slave routes, or Australia's extensive networks of Aboriginal exchange systems and the Pacific Island routes of Moana Vaku. Further examples would be routes of exploration or migration.

Landscapes may have many layers of successive historical development and emotive associations allowing us to read, in our visual analysis, their past histories (Hoskins 1960: 13-19). They may also contain distinct contemporary cultural landscapes of use or interaction, as Baker found in his study of the Yanyuwa's move from bush to town life in the Borroloola region (Baker 1999: 20-3). Meinig (1979: 34) reminds us 'Thus we confront the central problem: any landscape is composed not only of what lies before our eyes but what lies within our heads'. Meinig's stimulating discussion presents ten ways of interpreting a landscape. Curiously these do not include 'landscape as story', a vital concern of this paper.

So any one landscape viewed from varying perspectives assumes new values and meanings. To quote Susan Buggey; 'Landscapes have always been seen in many different ways by different viewers' (Buggey 1998: 1). These differences resonate with powerful memories of my own fieldwork near Lake Eyre in 1982. Linguist Luise Hercus, senior Aboriginal men Ben Murray (Fig. 2) and Arthur Warren were recording important places, significant for religious or mythological associations in local tradition or with more recent historical events. My concern was with the archaeology associated with these places. As we travelled that immense desert landscape I was constantly impressed by how different were the landscapes Ben Murray and Arthur Warren were viewing from those I was observing. Theirs were numinous landscapes of the mind, peopled by beings from an ever-present Dreaming whose actions were marked by the features of the created landscape. It was certainly, as Salman Rushdie had perceptively recognised (when travelling in central Australia with Bruce Chatwin), a landscape 'mapped by stories' (Rushdie 1992: 232). My landscape, apart from a personal response to the beauty of those arid lands (landscape as aesthetic?) was a more scientific, mental construct. It was phenomenal, based on the physical evidence, a story of landscape formation reflected in geomorphology, and of past human activities reflected in accumulations of discarded artefacts. Different sets of values and meanings thus emerged, intangible and tangible, for components of the landscape we crossed together, derived from intangible and tangible evidence. Yet each had validity. They established complementary sets, both vital to understanding a multi-layered past and its present significance.

To consider Aboriginal cultural landscapes therefore involves awareness of a range of significant meanings that may be daunting to those of other cultural traditions. It is no hard task to regard the features of the landscape as representational, symbolic of the presence of ancestral beings from the Dreaming. To move beyond this to accept these features as embodying the actual living presence of spiritual power and involving embodied, direct interaction with this makes demands of a different dimension. Yet the move is essential to understanding. Even if the encounter cannot be shared fully by those of other traditions, its cultural importance can be recognised and respected. 
Deborah Bird Rose, in a recent article (Rose 2000: 289-90) considering performance and ceremony in the context of place and country, writes 'place can be understood as a site of multiple presences and encounters ... [it] is also intensely political'.

Aboriginal nomadology, unlike transience, is set within the political and sacred geography of country. The place is not pause ... as much as it is return. Living things are coming and going, and, most importantly, returning.

A country includes a plurality of places, and people have rights to travel in, learn about, and undertake ceremonial and daily responsibilities for more than one country ...

Dreaming tracks and marks endure as memories and sites of power; human traces last for a while until they are washed away. The traces that remain when the person that made them is gone are both memory and promise ...

Every departure promises a return, and every return is a moral action, a promise fulfilled.

\section{The case study: a cultural route in the storied cultural landscape of exchange, Pukardu Hill red ochre expeditions}

Long distance exchange and social, ceremonial linkages are a feature of Aboriginal Australia. The continent is overlain by a matrix of such networks, often continent-wide, binding individuals and societies.

The routes along which people and goods move were, and are, traditionally ordained in the lines of travel of the ancestral beings when, in the Dreaming, they created the land and its features, at the same time establishing the law governing human actions within them. These lines of travel, or cultural routes, are often called Dreaming Tracks or, if associated with particular mythology or song cycle, Story Lines, Song Lines. The ancestral presence and power is maintained by ceremony and by singing the stories of the Dreamtime events at the relevant locations, regarded as places of power. This also maintains and disseminates cultural knowledge of the routes, their distant components and the geography of the landscape (see Strehlow 1965, 1970; Myers 1986; the current research of Hercus and Potezny in the Lake Eyre Basin). As Myers stresses, the land, like its people, is made of stories, not atoms.

The Urumbula song cycle and its route exemplify this. One 900 kilometre-long part of the route and its associated places are the subject of an Eastern and Lower Southern Aranda song cycle (the Urumbula or Native Cat story - see Strehlow 1965, 1970). This song cycle crosses the country of several distinct social and linguistic groups, linking Amewara (modern Port Augusta) with distant centres on the northwestern fringes of the Simpson Desert. Each group would care for their sections of the route and its significant places, where they sang the appropriate parts of the song. These would be in the Aranda language, not that of the local area, even when celebrating a feature located at Port Augusta, where the Parnkalla (Punkala) language was spoken (according to Strehlow 1970: 94-5; it is now regarded as situated on the boundary between that language and the area of Nukunu language - Hercus pers. comm. 2001). Strehlow $(1965 ; 1970)$ cites several similarly extended song cycles rooted in places and the routes linking them, as does Myers (1986: 61-4). Myers stresses that these routes, with their stories, illustrate how the Dreaming and landscape ('country') relate, and how 'country' is a continuous entity. The stories are 'punctuated by place', and spatial 
relationships. The narrative also 'emphasises the motivations and appropriate relations between people "from one country" (sharing), the geographical expanse of such relations, and the violent consequences of failing to respect the rights of others' (Myers 1986: 61 and Myers 1993). The practical wisdom of such law in harsh, uncertain desert environments need not be laboured. However this is but one social aspect (a 'mutual claim to hospitality and protection') of what is primarily a matter of group and individual ritual cooperation and affiliation (Elkin 1934: 174).

In the 1930s, Elkin undertook field work among the groups of the Lake Eyre region and the Musgrave Ranges. It impressed upon him the importance of the entity of the 'track' or 'path' with its stories as distinct from 'country' or 'place'. It determined a person's 'dreaming', so was fundamental to personal and group identity. Relationship to the extended story lines could forge important links: 'myth and ritual constitute a cooperative possession and activity, which binds together local groups even of different tribes' (Elkin: 1934: 171).

The extent of these storylines and associated exchange networks is measured in thousands of kilometres. They are among the world's most extensive systems of human communication recorded in hunter-gatherer societies. Their significance, however, lies not only in their extent and our anthropological or archaeological construction of this, but in the social importance accorded them by Aboriginal people.

Goods moved along these routes through personal/individual transactions at nodes in the exchange networks, those special meeting or ceremonial centres where groups came together for social, political or ritual events. Some items, however, were acquired through special expeditions to their source, such as the cakes of red ochre from the famous deposits at Pukardu Hill near Parachilna (Howitt 1904: 711-12). Pukardu Hill lies at the southern extremity of a complex exchange network running through the Lake Eyre/Cooper Basin in eastern central Australia (Fig. 1). It spans the continent, linking the Gulf of Carpentaria in the far north with the southern oceans (see McBryde 1997b).

This case study raises interesting comparisons with El Camino de Compostela. For the Diyari of the Cooper to collect ochre from Pukardu Hill was also to make a ritual, ceremonial journey. Those participating were specially chosen senior men and young men still undergoing their training in the law and ceremonial life. The route taken was prescribed by convention as were the camping places along it, where ceremonies would be held.

The routes followed by various groups undertaking expeditions to the ochre quarries (Diyari, Yandruwantha, Wangkangarru and Wangkumara) followed closely the actual path taken by the ancestral being concerned. This was seen as a 'ritual necessity, for ritual is a re-enactment of the past, a past which is recorded in mythology' (Elkin 1934: 173). Elkin stresses that the line of the track is as important an entity from this perspective as the special site or sanctuary. The approach along the correct path is thus both ritually and historically determined:

Travellers following the path of their totemic hero or heroes are free and safe, at least as far as other members and local groups of their own cult totem are concerned. A notable instance of this is the expedition for red ochre from north-eastern South Australia down to the deposits near Parachilna. The group used to 


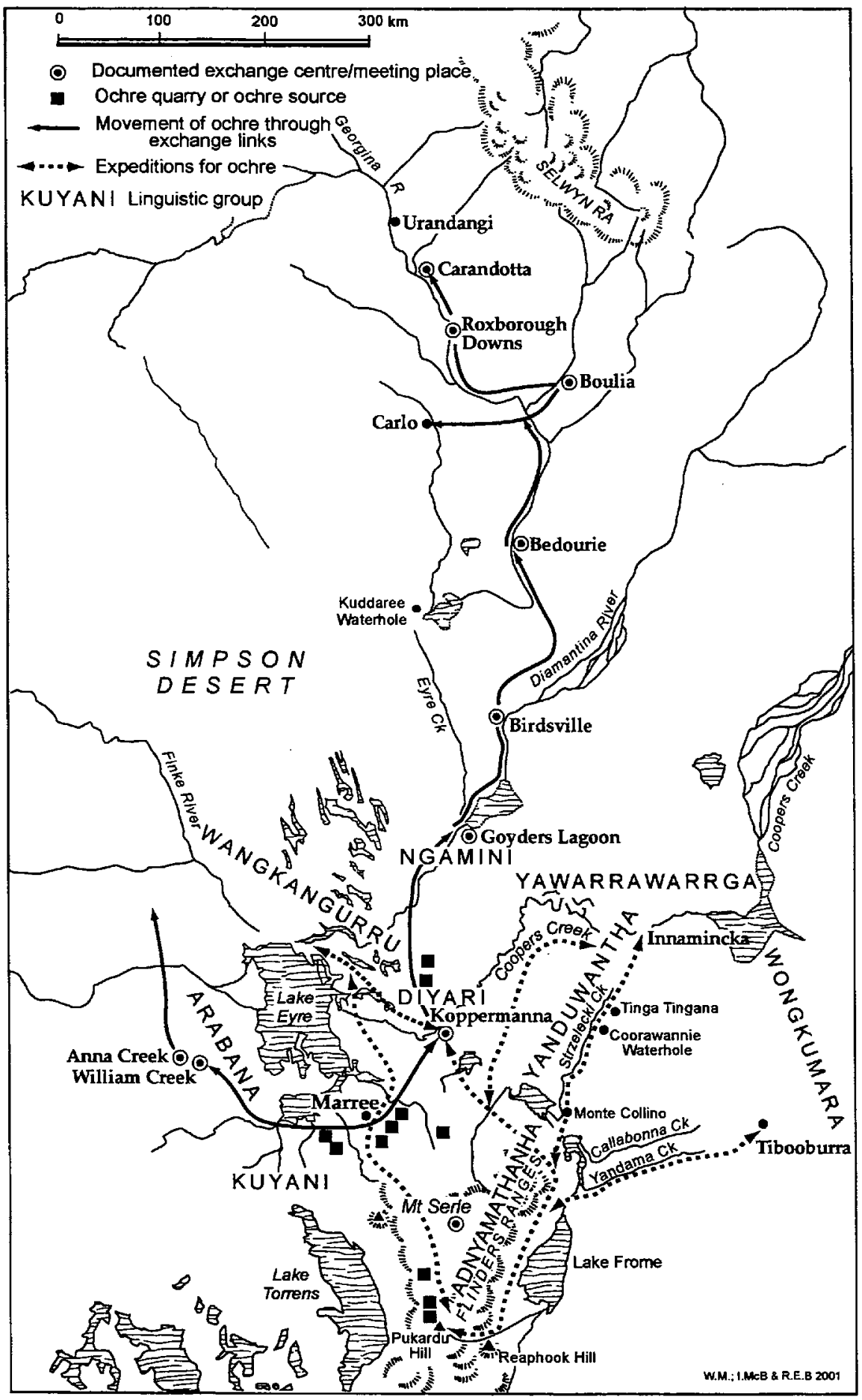

Figure 1 Lake Eyre Basin showing the exchange linkages through which red ochre from Pukardu Hill travelled and the routes followed by the red ochre expeditions. 
follow the route of the mythological actors, who were ultimately responsible for the formation of the deposits (Elkin 1934: 174).

The journey took place each year in late winter, members of the party (the 'Bookartoo men') being chosen in July or August. This ensured that the expedition was made when conditions for travel along the difficult desert route of over 500 kilometres would be optimal. The journey south took several months following the Strzelecki Creek and then the eastern slopes of the Ranges before turning west near Blinman to reach Pukardu Hill (Fig. 1). The Diyari's neighbours to the east, the Yandruwantha people, made similar expeditions along this route. The Wangkumara of northwestern New South Wales travelled to Pukardu Hill for ochre as well, following Yandama and Callabonna Creeks to the eastern slopes of the Ranges. Knowledge of Wangkumara expeditions comes to us from senior man George Dutton, also Cecil Ebsworth Oeremy Beckett pers. comm. - Beckett worked with George Dutton over many years - see Beckett 1958: 19 and Beckett 1976; for Cecil Ebsworth's life pers. comm. Luise Hercus; Cecil Ebsworth pers. comm. to writer February 1991).

Groups living northwest of the Ranges also made special journeys following designated routes along the western slopes of the Ranges. These were the Wangkangurru of the Simpson Desert and the Arabana who held country south of the Desert and Lake Eyre. Direct records of these journeys come from Mick McLean Irinjili, senior Wangkangurru man from the Simpson Desert (Fig. 3). His father was a member of one of the last expeditions from this area to Pukardu Hill in the 1880s. Mick McLean Irinjili and Jimmy Russell Wanga-mirri (Many Mornings) and his brother Leslie Russell Wanga-pula (Two Mornings) (Fig. 3) shared their experiences and knowledge with linguist Luise Hercus in the 1960s and 1970s. They stressed the importance of the red ochre expeditions and the special qualities of the ochre from that quarry (Hercus pers. comm.).

Jimmy Russell Wanga-mirri belonged to a Wangkangurru group of the Kallakoopah Creek on the eastern side of the Simpson Desert. When he was a youth in the early 1900s the ochre expeditions were under severe pressure as they were considered disruptive to pastoral activities (see Jones 1984). Also, by then most Wangkangurru had already left the Desert (Hercus 1985). In about 1920 Jimmy Russell Wanga-mirri joined a group of Diyari and Yandruwantha men who travelled from the Desert via Marree to Pukardu Hill. On this journey, he learnt the song of those returning from Pukardu Hill; in 1976 he sang it for Luise Hercus:

They sing the Pukardu song ... for setting out and returning. They sing the song of Pukardu Hill, they sing it for a long time.

The words match those of the song of the Bookartoo men recorded by Gason (a mounted police officer stationed in the Lake Eyre region in the 1870s) who wrote of Diyari expeditions to the Flinders for ochre (Gason 1879: 282, 1886: 44ff). This record testifies to the power of oral tradition as well as to the prestige of the ochre expeditions and participants.

For all these groups ochre was locally available in their own territories (cf. Horne and Aiston 1924: 34). However, that from Pukardu Hill was especially valued. It was reserved for decorating bodies and equipment for the great inter-group ceremonies, while some was kept as a prized good for important exchange transactions at such meetings. Having been brought hundreds of kilometres from the Flinders Ranges to 
Cooper Creek or the Simpson Desert it might then travel equal distances to exchange centres such as Goyder Lagoon or Boulia, and from these be taken even further. The term yamparnu was used for the prized Pukardu ochre. Pigment from the small local sources which lacked its symbolic values was called arkapa by the Arabana and Wangkangurru, and karku by the Diyari and speakers of languages to the south of Lake Eyre. It was said that none of these other ochres had the same sheen as yamparmu.

The expedition itself followed careful preparations. Messengers carrying specially incised batons were sent ahead to advise the owners of the quarry that ochre was required. Mick McLean Irinjili and Jimmy Russell Wanga-mirri described their experiences for Luise Hercus, drawing also on their memories of talks with older senior men. Members of the expedition carried goods to exchange for the red ochre. Jimmy Russell Wanga-mirri spoke to Luise Hercus in 1976 of the goods brought south for the quarry owners (Luise Hercus pers. comm.):

They came on foot, from far away, from beyond, they came from the sandhill country ... carrying big fighting boomerangs ... In exchange they give black (manganese), boomerangs, sticks suitable for rubbing to make fire, they give downfeathers - and sometimes even grass-seed flour in a bag, a bag meshed in the same way as when they make a net. And they take nets too.

The journey had its own rituals. The Bookartoo men always followed the same route, and carried special seed cakes called malhiri for ceremonial meetings with other Aborigines on the way. Their bodies appropriately painted, they performed the songs and dances specific to particular places as they travelled (Fig. 4).

At Pukardu Hill they fashioned round cakes from the soft quarried ochre and 'baked'm like a damper' (Mick McLean Irinjili) (Fig. 2). These carefully prepared cakes were then carried on the long journey north, each man taking a load of up to thirty kilograms. Their return to the prearranged camp site in their own country was the occasion for formal reception and ceremonies. Those who had remained behind prepared elaborately; huts were built, the men made head-dresses for the ceremony and the women special seed cakes to feed the participants. The ceremonies were often associated with that called the mindari. This was an important element in the ritual life of Lake Eyre groups, and associated with emu mythology (Elkin $1934: 187-9$ ). The roles of ancestral emu beings in some of the creation stories for Pukardu ochre deposits will be discussed later.

Reverence for the Pukardu Hill ochre has been recorded among all Aboriginal groups of the Lake Eyre/ Cooper area; the rare qualities of its colour may to a great extent account for this. It is a brilliant, shimmering, deep violet-hued red. In many parts of northern and central Australia such shimmering brilliance is considered symbolic of life and wellbeing. It is associated with, and can even represent or bestow, ancestral power; hence its importance in art and ceremonial. Morphy (1989) has analysed this and the concept of biryun (shimmering brilliance) recorded by Thomson as significant for Arnhem Land people.

Pukardu Hill itself is a place of great traditional importance for local people and to those of the Cooper, Lake Eyre and the Simpson Desert as well as northwestern New South Wales who made the journey to Pukardu Hill to acquire ochre. These expeditions were part of ceremonial life for these groups associated with song and ritual performances en route and following the return. They are still remembered as significant, 


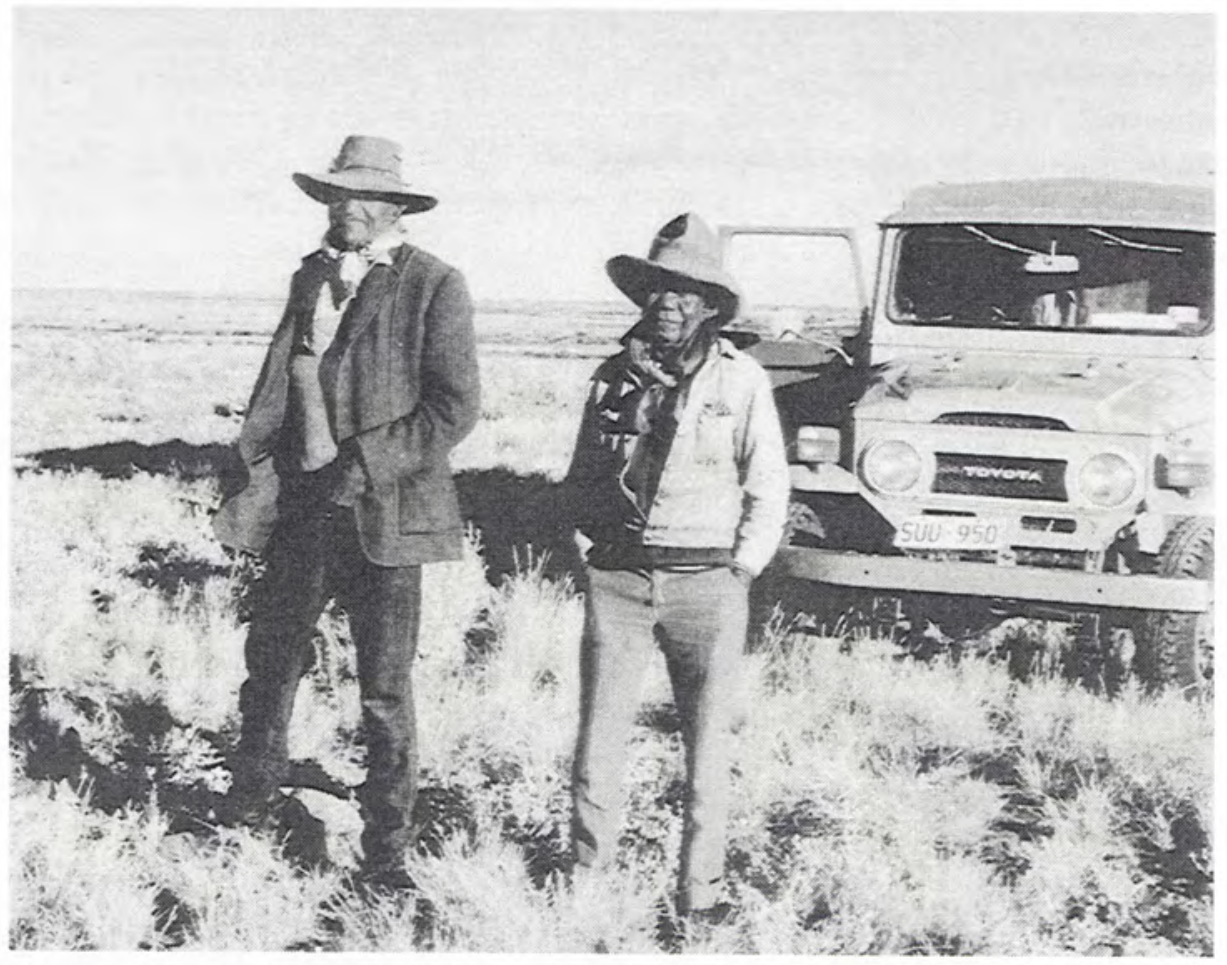

Figure 2 (top) Ben Murray and Jimmy Russell Wanga-mirri at Ditjimingka in 1976.

Photograph from the collection of Luise Hercus, reproduced with her kind permission.

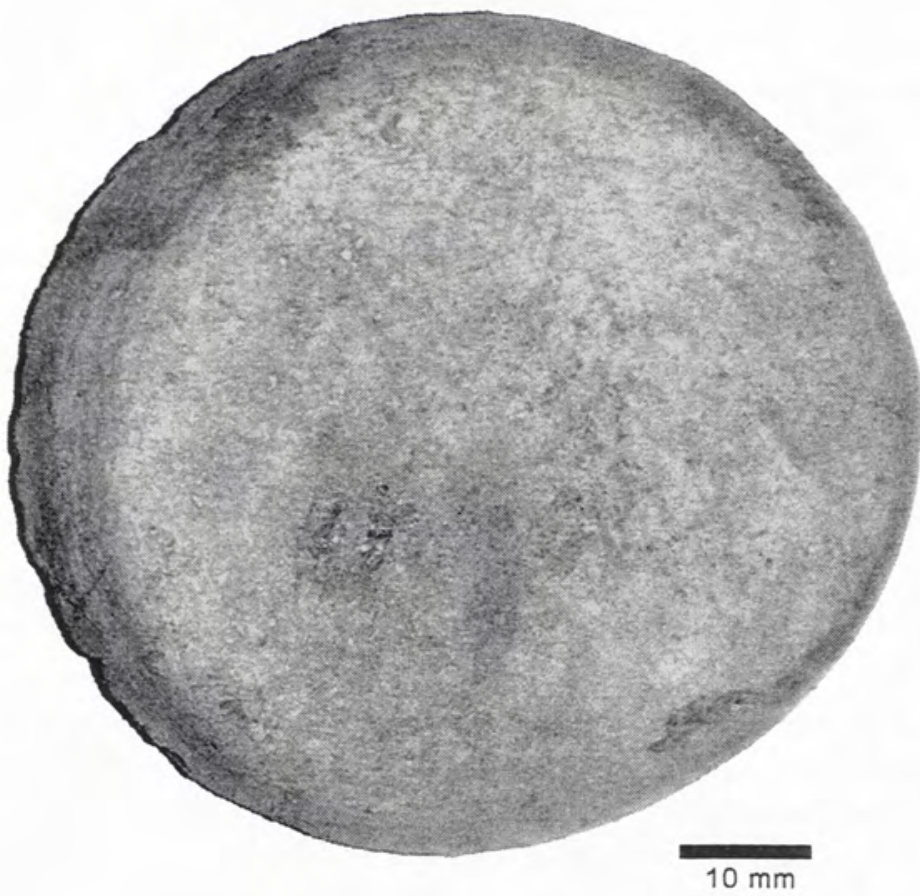

Figure 2 (bottom) A cake of Pukardu Hill ochre from

Coopers Creek in the collections of the South Australian Museum.

Photograph by Philip Jones, reproduced by courtesy of the South Australian Museum. 


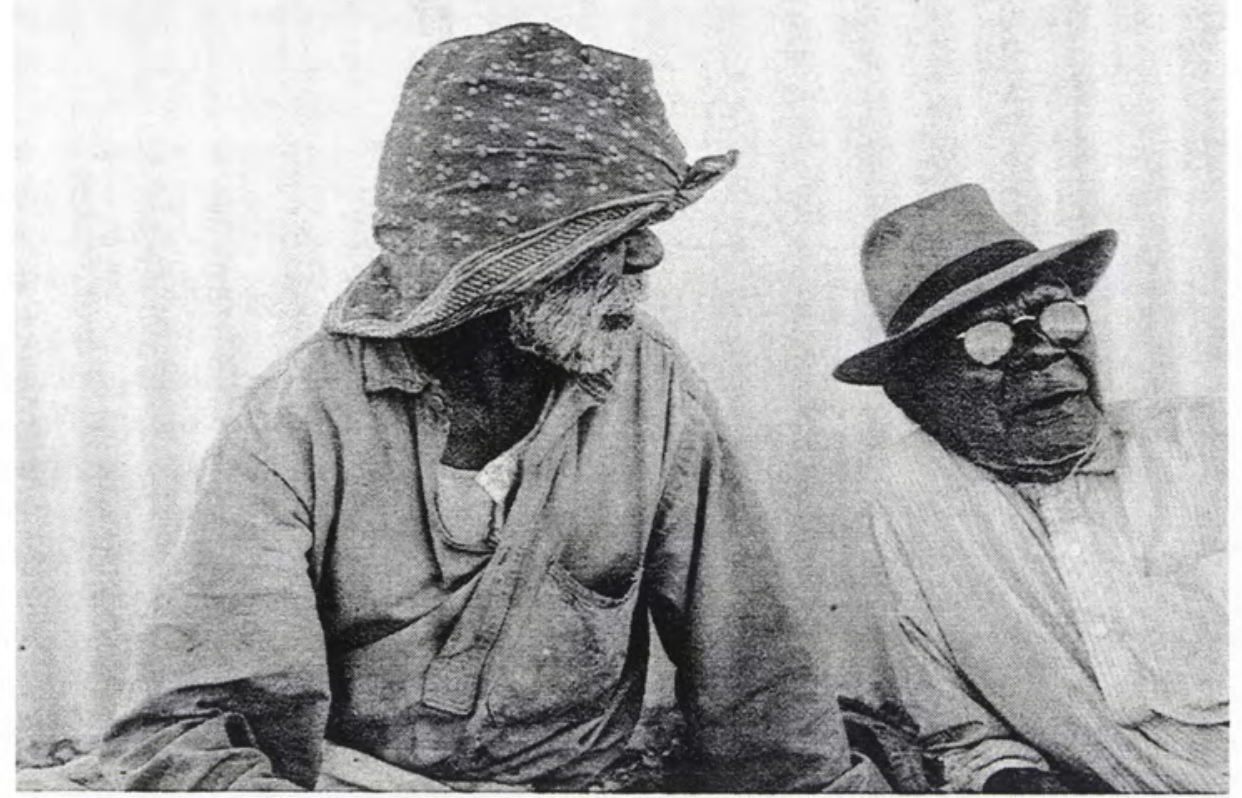

Figure 3 (top) Leslie Russell Wanga-pula and Mick McLean Irinjili at a meeting with Luise Hercus and Sally White at Marree, January 1970. Photography by Sally White, from the Isobel White collection, AIATSIS Audiovisual Archive, reproduced courtesy AIATSIS.
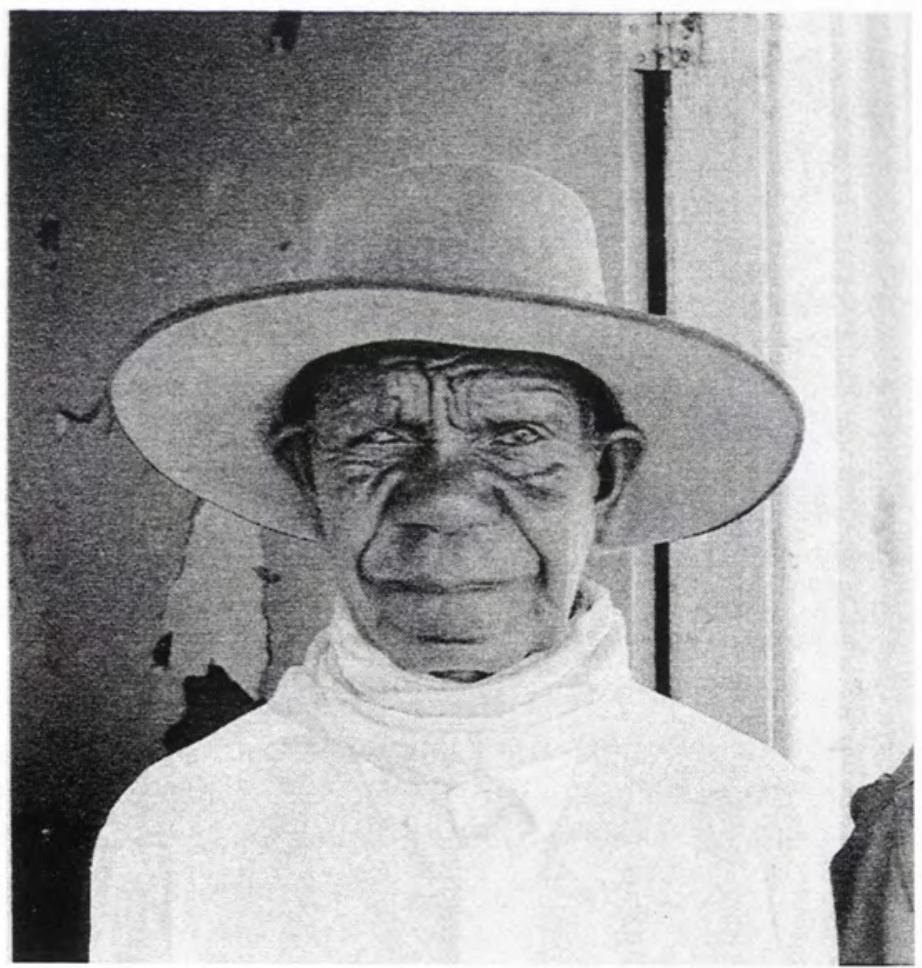

Figure 3 (bottom) Jimmy Russell Wanga-mirri photographed by Sally White at the Marree meeting. Reproduced courtesy the AIATSIS Audiovisual Archive (Isobel White collection).) 
though it is eighty years since such journeys were made. Of the ochre itself symbolic values were paramount, derived from the quarry place itself and from the spiritual importance of the journey. Any rarity value of the ochre is associated with these two aspects. Certainly the colour is distinctive, clearly an important quality. These physical and symbolic values ensured that Pukardu ochre was reserved for special use. Ochres are readily obtainable in the local environments of those who travelled to Pukardu Hill (Horne and Aiston 1924: 81 - referring to Wangkangurru country) as well as from Aroona near Pukardu Hill (Masey 1882). However they were not seen to hold symbolic values, and were used in more mundane contexts. "This [ochre from the Blinman group's quarry] is considered the "proper" ochre ... although plenty, hundreds of miles nearer, could easily be obtained (Horne and Aiston 1924: 34).

Confirmation of the special qualities of Pukardu Hill ochre, and the importance of the journey itself emerges in the unhappy history of conflict between pastoralists and Aborigines from the 1860 s (Jones 1984). In 1874 the government decided to resolve the problem and end the expeditions, by providing ochre to Aboriginal groups in the north. Unable to recruit local carters to collect and transport Parachilna ochre north they sent four tons of ochre from a Kaurna quarry near Adelaide to the German mission on Cooper Creek to be distributed to the Diyari. The missionaries did not report on the reception of this largesse. However Masey writing to the Port Augusta Dispatch in 1882 commented 'The natives would not use it. It did not give them that much-coveted shiny appearance that filled them with delight and admiration'.

Important stories recount the creation of the ochre deposits at Pukardu Hill. One of our earliest records comes from the nineteenth century traditional custodians (the Blinman subdivision of the Kuyani) of the ochre quarry. It was presented in the context of a conflict of land-use values that speaks poignantly across the years. In December 1904 Dr Shanahan of Hawker wrote to Dr Stirling, Director of the South Australian Museum, requesting his support in obtaining urgent government intervention to set aside the area of the ochre deposits as an Aboriginal reserve (Jones 1984: 3-6). Its continued use by its Aboriginal custodians was under threat from European mineral exploitation. Adelaide prospecting interests had taken out a lease, under the outrageously unfortunate name 'Sacred Land'.

In August 1904 local land holder Matheson of Nilpena Station had written to Hamilton, the Protector of Aborigines, presenting the fears of custodian King Harry and his hopes for reservation of the area. Matheson advised Hamilton of King Harry's own political initiatives, his plans for a 'muster of blacks' in Brachina Gorge. Matheson offered to escort Hamilton there to meet the Aboriginal chief custodian (Jones 1984: 19, note 34). Shanahan also contacted Hamilton, advising him not only of King Harry's concern (which he regarded as totally justified) but also warning of the projected meeting as a prelude to violent reprisals if the Aborigines' just claims were ignored (Jones 1984: 14).

At the end of the year Matheson and Shanahan, accompanied by a government geologist, visited the quarry guided by King Harry. Shanahan then wrote urgently to Stirling soliciting his support (Jones 1984: 3-6 gives the full text of this letter; see also Brock 1985, 1993). Stirling took the case to the Premier arguing the special Aboriginal value of the ochre: 'To deprive the natives of this would ... be a real act of unkindness'. 
In January 1905 the area was gazetted an Aboriginal reserve (Jones 1984: 19, note 35 Government Gazette SAO 26 January1905).

In his letter to Stirling, Shanahan provided documentation of the quarry's significance. He records the local legend of the creation of the ochre deposits (text from Jones 1984: 4, SAM Archives No 162 26/12/1904; Brock 1985: 33) (see also Figs 1 and 4).

Two dogs (= Kintacawoola) named respectively Kilowilinna and Perilingunina chased an emu (=Kuringii) starting from near Innamincka, down the Cooper passing through Tinga-Tingina, Caraweena, Monte Collina, Mr. (sic) Freeling (here the emu had a drink and left in the solid rock the imprint of its foot) the emu then skirted the western slope of the Flinders Ranges to Mr. (sic) Alick (this mountain the blacks maintain is the emu petrified), here it turned and ran through the Lake Torrens Plain, dodged once more and made for the Flinders travelling due East, the first hill it met was a man who had a pack of dogs one named (Thorijurra), a savage brute. The bird raced up the staircase. (I will define the staircase later on) but the dogs caught it on top of the hill. The man assisted in the bird's despatch with a yam stick and was instantly turned into a hill ... The blood from the emu (Emu's blood = Kuringie Warragurta) now forms the ochre (Murragurta) deposit at the sacred cave (Yerkinna).

Opposite the Yerkinna cave, due west on the next steep hill and situated about a quarter of a mile from it is another cave into which the dogs went for a rest and there died, the dogs which perished there after death rolled down the hill and are now symbolised by huge dolomite limestone boulders rounded off by the influence of rain.

The original dogs of the chase - Kilowilinna and Perilingurina - are represented by two high mountains, one St. Mary's Peak the other unnamed in the Flinders Ranges.

In the same letter Shanahan outlines some of the ritual activities undertaken by parties arriving at the site, having previously advised the custodians of their intentions through special messengers. Neglecting this courtesy was a serious office (Jones 1984: 8 citing Reuther's reference to the rules of exchanges). Ritual activities took place in specified locations while certain areas around the quarried deposits were restricted to all but senior custodians. Women were not allowed to approach the area at all; they could however act as messengers for an impending expedition.

The area of the quarry was regarded as 'not only sacred, but their richest resource'. Considering this, as well as the widespread distribution of its products to distant groups, and that it is used in nearly all of their ceremonies and is essential in the performance of the majority of their rites' Shanahan concluded 'we can easily understand the attitude of the aboriginals and the justice of their demands' (Jones 1984: 3).

Appropriation of this resource by mining interests would thus have catastrophic impact on vital cultural activities among many Aboriginal groups of the region. King Harry told Shanahan also that loss of access to the deposit would result in his death, and endanger his successors, no longer able to fulfil their responsibilities to this sacred place.

For the decades following the end of the ochre expeditions, anthropologists working in the Flinders Ranges and adjacent regions record continuing knowledge of the quarries, their famed ochre and the stories of its origins. Jones refers to the work of 
Mountford, Fry and Tindale. Tindale was told of the trade in Pukardu ochre by Ngadjuri people living south of the Ranges - a link mentioned by Mick McLean Irinjili talking with Luise Hercus in 1968. In 1937 Mountford recorded Diyari ceremonial songs known to local Adnyamathanha at Nepabunna, attesting both to the ritual links created by the red ochre expeditions, and that their songs could still be sung despite severe social dislocation and cultural loss: 'the song still remains which names the land over which it sings' (Heidegger 1971: 97).

In their own countries the Lake Eyre groups also maintained stories of the ochre deposits in distant southern lands, known from the days of the expeditions. Jones notes Reuther's reference to Dieri/Diyari stories of the ochre's formation in the emergence from the earth of a mura (Timpiwalakana) (Jones 1984: 7). Other stories involve different ancestral beings who have links with, or who travelled through, the lands of groups sending expeditions to Pukardu Hill. Some of these stories were recorded in the 1920s by George Aiston who lived in Diyari country for many years. He was a serious student of Aboriginal culture, with direct knowledge of the red ochre expeditions, presenting in publication local accounts of the ochre's creation from the blood of the dog Marindi (Horne and Aiston 1924: 128-30).

In the old days, before men were, there lived in this valley a jecko lizard. Adnoartina was his name. Every day this lizard would climb a big rock and would sing aloud so that all could hear. 'Come out and fight, come out and fight'.' Now the big dog Marindi came past that way, and hearing the challenge, he bounded up the dry creek bed yelling all the way: 'I am come, I am come'. Adno-artina had a look at the dog. He saw beneath his sharp pricked ears the enormous fangs. He saw the huge bulk over which the white tip of his tail waved, and the more he looked the less he liked the prospect of the combat. 'I will fight you later', he said. 'Later you will make a feast for my pups', returned the dog, as he curled himself up at the foot of the rock. Now, like all jecko lizards, Adno-artina sees best when it is dark. So as the sun went down he tied a hair string round the root of his tail to make him fight better, for then his courage could not run into his tail. It was now dark, for when the sun goes down the darkness springs out. He crept to the ground and once more rang forth his challenge. 'Come out and fight'. Marindi the dog leapt up and tried to catch Adno-artina by the back of the neck and shake the life out of him. But the lizard ran in low beneath the terrible fighting teeth. He seized the dog by the throat and hung on. In vain Marindi shook him and scratched at him with his claws. The sharp teeth sank in and in, until at last the red blood spurted out. And so from that time on all jeckos - now a puny race compared with their ancestor - have a constriction around the root of their tails.

The blood of Marindi the dog dyed the rocks on the banks of the creek, and from this the red ochre is obtained to this day.

The little creek became the Mecca, not only of the Kooyiannie, but also of the Dieri, the Wongkonguru, the Ngameni and the Yaurorka tribes. There only could the real dog's-blood ochre be obtained, and none other should be used ...

Crooked-foot Peter, the headman of Cowarie ... tells the following story:

'Two moora emu jump up. Dog him live in hole. Chase 'em emu. Emu run. Dog run. Pass 'im Killalpaninna. Pass 'im Dulkaninna. Pass 'im Apawandinna. All time emu run. Dog run. Pass 'im Farina. Pass 'im Beltana. Emu him run up big hills. Dog him catch 'em emu. Kill 'em. Blood him jump out. Ochre grow. Lot good ochre.' This, as near as I can remember, is the story in Crooked-foot Peter's own 


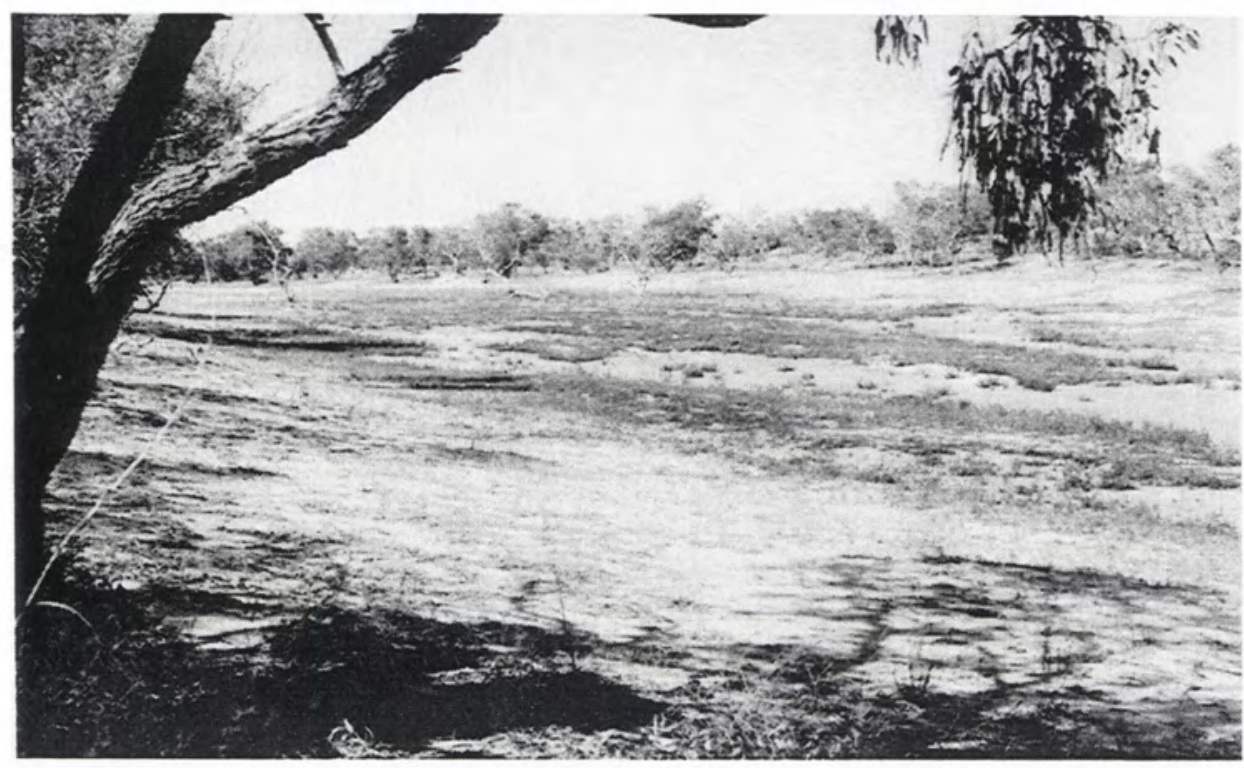

Figure 4. Coorawannie Waterhole on Strzelecki Creek, a traditional place for red ochre expeditions to camp and hold ceremonies. Photographs by Isabel McBryde, September 1986.

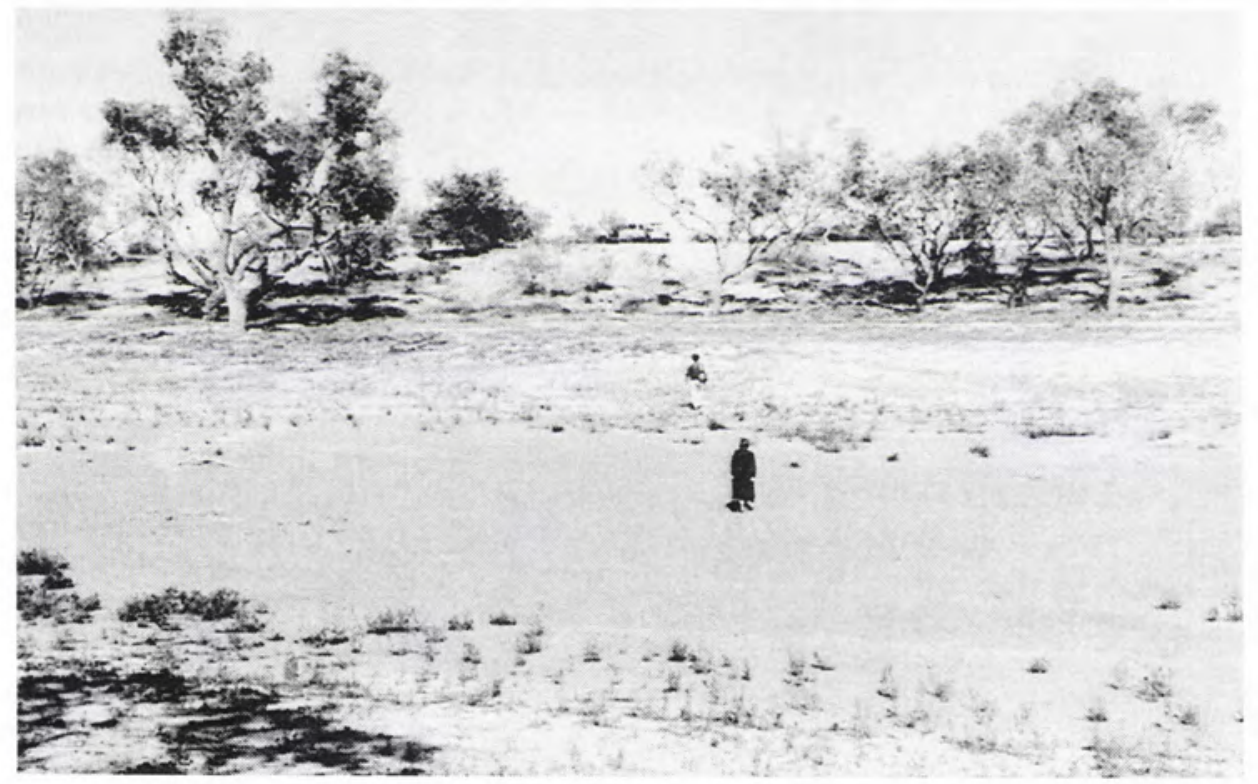


words. And ever since, he tells us, the good ochre came from this district. From Queensland, the Cloncurry tribes sent their bean-wood shields in exchange. From New South Wales were traded the light shafts for spears. From Alice Springs worked kirras were sent. Then, loaded each with 50 pounds of red ochre, they must begin their toilsome way homewards. Over 300 miles they travel, keeping clear of hostile people, through whose territory they must pass.'

In the 1930s anthropologist AP Elkin during his field work with the Lake Eyre groups encountered a number of emu myths related to the Parachilna ochre (Elkin 1934: 187-9).

I learnt bits of it (the emu myth) here and there. Thus, some Yauarawaka men near Birdsville said that the emus started from the Mulligan in south-west Queensland and travelled south, dancing. Near Apamana they were joined by two other emus, itikaru and tjapara, who accompanied them to Cuttapirie, where they were killed.

Some Yantruwanta informants said that two emus, a male and female (in some version there were four of the birds), called Turkurendja, were feeding around Cutrabelbo water-hole and Kunapururu, about twenty-five miles (40 kilometres) down the Cooper from Innamincka Station. A man and woman were travelling along not far off, the woman looking for grass seed to grind, and the man hunting and making for his next camp at Kudriemitchie water-hole. His dogs started the emus and chased them south-west and around the western side of the Flinders Range to Parachilna, where the emus went into the hill and were changed into a deposit of red ochre. A steep hill standing by itself near Parachilna is the female dog.

I obtained another version from an old Dieri man whose patrilineal cult-totem is pandjini, an emu mura-mura who 'made' red ochre; this old man spoke of himself and his father and others of his country at Lake Peragundi as all 'red ochre mob'. His myth was that five dogs chased an emu from two mindari water-holes near Innamincka past Murnpeowie, across to Stuart's Creek and down to Port Augusta, where it went into the ground for a time, but after a while it came up again and travelled north to Parachilna, where it went into the ground altogether, and gave rise to the deposit of red ochre in that vicinity.

The Arabana version is slightly different, for though emus are chased by dogs, yet the ochre is said to be associated with one of the latter, rather than with the former. But I may only have received a fragmentary account. It runs as follows:

Two wild dogs chased some emus from Kalburugwa, a small salt lake near William Creek in Arabana country, to a cave at Beltana, where one of the dogs, a female, gave birth to pups. The blood associated with this event caused the local deposit of red ochre. The two dogs then sang. The male dog had a white mark down its forehead and around its neck. The dogs, changed to stone, can now be seen at this cave. It is said to be very dangerous to touch the female dog: in fact to do so would cause the world to come down. No women, not even if this be their cult-totem, can enter the cave, though one informant said that women with this cult-totem know the songs; such a woman plays a string game during the singing.

For Elkin this range of evidence from Lake Eyre groups strongly reinforced the association of red ochre, especially the Parachilna deposits, with the emu ceremony and emu mythology. In one ceremony he recorded the red ochre men entered the ceremonial ground with the emu's heart wrapped in string. They represented the returning expedition members with the prized ochre, their arrival celebrated with a mindari ceremony. 
The stories of the emu and the creation of Pukardu Hill ochre deposits were passed across the generations. In 1968 Mick McLean Irinjili, Jimmy Russell Wanga-mirri and Murtee Johnnie discussed them with Luise Hercus. All men remembered 'Crooked-foot Peter' (Aboriginal name Thalka-nguyu), whose version of the story is in Aiston's account we have just considered. Mick McLean Irinjili made the following comments (Luise Hercus transcript of recording 1968).

The ancestral emu walk about there and go down south then, the dogs been chase ' $m$ then. He goes right down to Parachilna, further than that, to Point Pearce. Turn ' $m$ back then and comes back this way and chase ' $m$ all the way to Parachilna then, that Pukardu piti [quarry], kill ' $m$ there. Those same two dogs from Cowarie are in all the history, all the Mindari history. They go down as far as the Nukunu crowd and the Point Pearce mob. People from the Peterborough side (Ngadjuri) come in it too.

\section{The red ochre expeditions' line of travel as an Aboriginal cultural route of outstanding heritage significance}

The long-distance lines of travel for the red ochre expeditions from the countries of Lake Eyre groups and that of the Wangkumara from the northeast are clearly of outstanding significance as cultural routes. They focus on the quarried deposits of ochre at Pukardu Hill. This place holds paramount social values as cultural heritage in its custodians' country. Beyond, it holds comparable mythological and spiritual significance, being revered by groups throughout the region whose members once took part in the red ochre expeditions. From other perspectives significant values may be cited. To anthropologists and archaeologists it is famous as the region's most important source of red ochre, of pigments transported and exchanged across vast distances in a cultural landscape of exchange that has outstanding significance in global contexts (Mulvaney 1976; McConnell 1976; McBryde 1997c). This significance relates not only to the extent but also to the complexity of its social contexts.

The cultural routes of the ochre expeditions link this focal resource with series of storied places associated with the ritual life of the societies involved as well as their acquisition of a valued good. The locations constitute places of power joining the present to the plane of being of the Dreaming. The ceremonies held at each constitute 'the pulse of continuous creation' (Rose 2000: 294), their numinous force being still accessible. They hold vital past and continuing spiritual values (Morphy 1996). The lines of travel themselves are a distinct entity, clearly defined by tradition, still known and respected as such by relevant Aboriginal groups. Indigenous perceptions would thus, as we have seen, substantiate the recommendation to International ICOMOS by its Vice-President that the line of travel itself be the entity to designate as the cultural property rather than specific places along the routes. These then may be regarded as holding associative value derived from the intangible entity, the mental construct of the cultural route with all its powerful meanings.

Through the period of European settlement of these lands new meanings and values may have been attached to those places, even to the line of travel. These meanings derive from their associations with human activities in the historical, remembered past. They may range from the ceremonial to the social, associative in relation to belief systems or commemorative, marking events important collectively to the group or to its 
individual members. Research by archaeologists and anthropologists is adding new layers of meaning from other perspectives, from the knowledge systems of western science opening alternate windows onto the distant past of this continuing cultural landscape (Peterson and Lampert 1985; David et al. 1993; Smith et al. 1998).

Susan Buggey reminds us that such traditional cultural landscapes, in Canada or Australia, (Buggey 1998: 16)

are not relicts, but living landscapes which encompass the cosmological, mythological, and spiritual worlds interwoven with their peoples' day to day activities of living from the land. The seasonal round of life on the land, practised over millennia, relies on the intimate connection of human and animal movements. Bequeathed through oral tradition from generation to generation, Aboriginal traditional knowledge embodies the relationship of the people to the land through narratives, place names, sacred sites, rituals and behaviour patterns.

The cultural landscape of exchange, and its expression in such cultural routes as the red ochre expeditions' line of travel, are outstanding elements in Australia's Aboriginal cultural environment. They demand recognition at national and international levels. But this must involve cross-cultural consultation, appropriate documentation and management that is sensitive to complex demands. Above all it must be fully responsive to the concerns of the custodial societies, recognising and respecting these as fundamental to cultural identity. As such they become issues of wider social concern. Jonas argues thus in the context of social justice, discussing considerations of the past, of history, and protection of cultural heritage places (Jonas 2001). It therefore also becomes an issue in national Reconciliation, creating another layer of meaning beyond concerns over the representativeness of the international listing of World Heritage properties.

Elsewhere I have discussed these aspects in the context of heritage management, especially the criteria that might assist evaluation of such cultural entities (see McBryde 1997c: 12). Here it is sufficient to stress the multi-layered nature of the task and the respect and sensitivity it demands of all involved in the exercise.

In considering recognition of cultural heritage places so far explicit stress has been given to the international level of UNESCO's 1972 Convention. However further considerations arise. At present Australia is engaged in important debates on national, state and local levels of significance for heritage places. This is in the context of major changes to heritage legislation and management responsibilities within the three tiers of Australia's federal government.

In this context the red ochre expeditions' cultural routes demonstrate the permeability of such levels or categories. They cannot accommodate the multi-layered complex values these components of indigenous cultural heritage hold in national and regionial contexts. The cultural routes can only be seen as holding national (or international) significance by accepting that this derives ultimately from their special social values within the cultural traditions of one particular group in one particular regional setting within the national demographic and geographic entity. Further, that group is now an Indigenous minority within a multi-cultural Australia. So plausible arguments might be made for 'local' significance and local heritage recognition in a schema designed to accommodate a limited range of 'national icons'. 
Yet the international recognition of the importance (in terms of global themes in human history and achievement) of those particular regional cultural traditions and history expressed in the ochre expeditions' cultural routes ensures that its national values cannot be denied. Further, it is easy to argue its strength when considered as comparable to the World Heritage listed cultural routes such as El Camino de Compostela. If Australian national lists are to be 'representative' in the same sense that I have argued for the World Heritage Conventions' listings, then the issues raised by places holding such multi-layered particular values must be resolved. Otherwise we risk not only diminishing the range of our national heritage but also denying due recognition and respect for the culture of our Indigenous societies. So the issue becomes vital for national Reconciliation as well as for questions of allocating the responsibilities of heritage protection and management between the three different jurisdictions of Australia's governance (local, state and Commonwealth).

If this process is to have integrity, then it must proceed with sensitivity to, and direct involvement of, Indigenous voices on cultural heritage, both the intangible and its embodiment in place. Management must respect the full 'voicefulness' (in Ruskin's sense) of the significant place in its cultural context, however strong the values and meanings it may have acquired in other contexts, such as the archaeological, scientific, aesthetic and historical (non-Indigenous). Here cross-cultural dialogue and understanding may develop, and ultimately resolve conflicts of competing values. The partnership of traditions, if not their melding, in joint-management regimes (as at Uluru Kata Tjuta and Kakadu National Parks) provides important opportunities for such Reconciliation.

The complexity of heritage assessment and management for the cultural routes across storied landscapes such as those chosen here as case study, will match the complexity of their roles in Aboriginal society, past and present. However it is a complexity that must be addressed. To incorporate them appropriately into the realm of recognised and protected heritage holding vital importance for the creating culture will not only extend and enrich our national perspectives on cultural heritage. It will also ensure that this is more representative of the richness and diversity of human culture, whether it be considered at local, national or international levels.

Such concerns resonate with Sally White's lifelong vision of an equitable society. They also explain her quick understanding of her Yalata friend Mangkatina's reference to her family's spinifex country homeland as 'orphaned country'. It expressed the sadness felt by Yalata families that those whose care should sustain its sacred places were living elsewhere in lands once Wirangu country, itself thus also 'orphaned'. Yet, as in the Flinders Ranges, the songs may still be sung, across the named but altered land, for travellers returning to memorialise significant places and renew contact with their numinous power.

\section{Acknowledgements}

The theme of this paper touches many issues. So I have greatly appreciated opportunities for discussion with colleagues: my thanks to Jeremy Beckett, Susan Buggey, Barry Cundy, Joan Domicelj, John McEntee, Luise Hercus, Philip Jones, Peter Read, Deborah Bird Rose, Sharon Sullivan and Vlad Potezny. Luise Hercus generously shared material 
from her work in the field with Mick McLean Irinjili and Jimmy Russell Wanga-mirri. The insights it provides have been important.

Special thanks are due to those whose country and history was traversed in the field. They generously shared their knowledge and I am grateful for the kindness of Cecil Ebsworth, Chippy Flash, Willy Harris, Pearl McKenzie, Ben Murray and Arthur Warren. It will long be remembered, also the brief meeting in 1982 with Jimmy Russell Wanga-mirri, then unable to travel with us.

It was a great pleasure to illustrate this paper with Sally White's photographs from her 1970 field trip. My thanks to Ronda Ramsay and Alana Harris at AIATSIS Audio-Visual Archives for their assistance in this, also to Geoff Hunt. Dick Barwick kindly and skilfully prepared the illustrations for publication. Winifred Mumford drew the base map of ochre exchanges with her usual flair and expertise. My thanks to them, and in particular also to Charlotte Palmer for advice on Sally White's fieldwork and records which gave their own special insights.

\section{References}

Baker, Richard, 1999. Land is life: from bush to town. The story of the Yanyuwa people. St Leonards, NSW.

Beckett, Jeremy, 1958. 'Marginal men: a study of two half caste Aborigines.' Oceania 29(2): 91-108.

Beckett, Jeremy, 1976. 'George Dutton's country'. Aboriginal History 2: 2-31.

Brock, Peggy, 1985. Yura and udnyu: a history of the Adnyamathanha of the North Flinders Ranges. Netley, SA.

Brock, Peggy, 1993. Outback ghettos: a history of Aboriginal institutionalisation and survival. Cambridge.

Buggey, Susan, 1996. 'Inter-American symposium on authenticity in the conservation and management of cultural heritage.' ICOMOS Canada Bulletin 5(3): 46-8.

Buggey, Susan, 1998. 'Towards a definition of traditional cultural landscapes'. Ottawa, Parks Canada HSMBC Agenda Paper 1998.

David, B, E Clayton and A Watchman, 1993. 'Initial results of PIXE analysis of Northern Territory ochres.' Australian Archaeology 36: 50-7.

Dessaix, Robert, 2000. 'Wanderlust'. The Australian's Review of Books Feb: 9-10.

Domicelj, J and D Marshall, 1994. Diversity, place and the ethics of conservation: a discussion paper. Canberra.

Elkin, AP, 1934. 'Cult totemism and mythology in northern South Australia.' Oceania 5(2): 171-92.

Gason, S, 1879. 'The manners and customs of the Dieyerie tribe,' in JD Woods The native tribes of South Australia. Adelaide, pp 253-307.

Gason, Samuel, 1886. 'From Mt Freeling to Pirigundi Lake', in EM Curr The Australian Race, vol. 2. Melbourne and London, pp 44-107.

Heidegger, Martin, 1971. 'What are poets for', in Poetry, Language; Thought (Albert Hofstadter translator), New York. 
Hercus, LA, 1985. "'Leaving the Simpson Desert" (a Wangkangurru account of the migration of 1899 and a discussion of the linguistic consequences of the migration).' Aboriginal History 9(1): 22-43.

Horne, $G$ and $G$ Aiston, 1924. Savage life in central Australia. London.

Hoskins, WG, 1960 [1955]. The making of the English landscape. London.

Howitt, AW, 1904. The native tribes of south-east Australia. London.

Jonas, William, 2001. Social Justice Report 2000. Aboriginal and Torres Strait Islander Social Justice Commissioner Human Rights and Equal Opportunity Commission, report no. 2000/2. Sydney.

Jones, Philip, 1984. 'Red ochre expeditions: an ethnographic and historical analysis of the ochre trade in the Lake Eyre Basin. A progress report'. Journal of the Anthropological Society of South Australia 22 (7): 3-10; 22(8): 10-19.

Larsen, Knut Einar (ed.), 1995. Nara conference on authenticity: Proceedings. Trondheim.

Lennon, Jane, 1997. Case study of the cultural landscapes of the Central Victorian Goldfields. State of the Environment Technical Paper Series (Natural and Cultural Heritage), Canberra.

Lévi-Strauss, Laurent, 2001. 'Sacred places and historic cities: preservation, governance and practicalities', ch. 46 in Serageldin et al., 2001.

Luxen, Jean Louis, 2000. 'The intangible dimension of monuments and sites with reference to the UNESCO World Heritage List'. Document on the www for International ICOMOS, pp 1-6.

Masey, TA, 1882. 'The red ochre caves of the Blacks.' Port Augusta Dispatch and Flinders Advertiser, 9 June 1882.

McBryde, Isabel, 1997a. 'The ambiguities of authenticity - rock of faith or shifting sands?' Conservation. and management of archaeological sites. 2(2): 93-100.

McBryde, lsabel, 1997b. " The landscape is a series of stories". Grindstones, quarries and exchange in Aboriginal Australia: a case study from the Cooper/Lake Eyre Basin', in A Ramos-Millan and Ma A Bastillo (eds) Siliceous rocks and culture. Granada, pp 587-607.

McBryde, Isabel 1997c. 'The cultural landscapes of Aboriginal long-distance exchange systems. Can they be confined within our heritage registers?' Historic Environment 13(3-4): 6-14.

McConnell, Ann, 1976. 'Aboriginal trade in the Lake Eyre region, Canberra 1976.' MA (Qual) thesis, Australian National University.

Meinig, DW, 1979. 'The beholding eye - ten views of the same scene', in DW Meinig (ed.) The interpretation of ordinary landscapes: geographical essays. Oxford, pp 33-48.

Morphy, H, 1989. 'From dull to brilliant: the aesthetics of spiritual power among the Yolngu'. Man 24(1): 21-40.

Morphy, H, 1996. 'Landscape and the reproduction of the ancestral past,' in E Hirsch and $M \mathrm{O}^{\prime}$ Hanlon (eds) The anthropology of landscapes, perspectives on place and space. Oxford, pp 184-209.

Mulvaney, DJ, 1976. "'The chain of connection": the material evidence', in N Peterson (ed.) Tribes and boundaries in Australia. Canberra, pp 72-94. 
Myers, Fred R, 1986. Pintupi country, Pintupi self: sentiment, place and politics among Western Desert Aborigines. Washington and Canberra.

Myers, Fred R, 1993. 'Place, identity and exchange in a totemic system. Nurturance and the process of a social reproduction in Pintupi society', in Jane Fajans (ed.) Exchanging products: producing exchange. Oceania Monographs 43, Sydney, pp 3358.

Peterson, N and R Lampert, 1985. 'A central Australian ochre mine.' Records of the Australian Museum 37(1): 1-9.

Rose, Deborah Bird, 2000. 'To dance with time: a Victoria River Aboriginal study.' Australian Journal of Anthropology 11(3) [Special lssue 12 The politics of dance]: 287-96.

Rushdie, Salman, 1992. 'Travelling with Chatwin', in Imaginary homelands: essays and criticism 1981-1991. London, Pp 232-36.

Schebeck, B, LA Hercus and IM White, 1973. Papers in Australian Linguistics no. 6. Pacific Linguistics Series A no. 36, Canberra.

Serageldin, I, E Shluger and J Martin-Brown (eds), 2001. Historic cities and sacred sites: cultural roots and urban futures. Washington.

Smith, MA, B Fankhauser and M Jercher, 1998. "The changing provenance of red ochre at Puritjarra rock shelter, central Australia, Late Pleistocene to Present.' Proceedings of the Prehistoric Society 64: 275-92.

Strehlow, TGH, 1965. 'Culture, social structure, and environment', in R and C Berndt (eds) Aboriginal man in Australia. Sydney, pp 121-45.

Strehlow, TGH, 1970. 'Geography and the totemic landscape in central Australia: a functional study', in R Berndt (ed.) Australian Aboriginal Anthropology. Nedlands, pp 92-140.

Titchen, Sarah, 1996. 'On the construction of "outstanding universal value"; some comments on the implementation of the 1972 UNESCO World Heritage Convention'. Conservation and management of archaeological sites 1(4): 235-42.

UNESCO, 1999. Operational guidelines for the implementation of the World Heritage Convention. Intergovernmental Committee for the Protection of the World Cultural and National Heritage, WCH 99/2, Paris.

von Droste, Bernd et al (eds), 1995. Cultural landscapes of universal value: components of a global strategy. Jena.

White, Isobel (ed.), 1985a. Daisy Bates, The native tribes of Western Australia. Canberra.

White, Isobel, 1985b. 'Mangkatina: woman of the desert', in Isobel White, Diane Barwick and Betty Meehan (eds) Fighters and Singers. Sydney, pp 214-26.

White, Isobel, 1993. 'Daisy Bates: legend and reality', in Julie Marcus (ed.) First in their field: women and Australian anthropology. Melbourne, pp 47-65. 